Check for updates

Cite this: RSC Adv., 2019, 9, 192

Received 25th November 2018 Accepted 12th December 2018

DOI: $10.1039 / \mathrm{c} 8 \mathrm{ra09680e}$

rsc.li/rsc-advances

\title{
Study on the effect of PolyFR and its FR system on the flame retardancy and foaming behavior of polystyrene
}

\author{
Yaqiao Wang, ${ }^{\text {ab }}$ Hanchuan Jiang, ${ }^{\text {ab }}$ Jingyue Ni, ${ }^{\text {ab }}$ Jianze Chen, ${ }^{\text {ab }}$ Hongfu Zhou, ${ }^{\text {ab }}$ \\ Xiangdong Wang (D)*ab and Fei Xin (iD *ab
}

\begin{abstract}
A new class of brominated polymeric flame retardant (PolyFR) which is a kind of environmental FR was researched. Hydrotalcite (HT), applied as an environmentally-friendly heat stabilizer for PolyFR, was investigated by thermogravimetric analysis (TGA). It presented the result that no more than $0.15 \%$ HT significantly improved the thermal stability during processing but excessive HT would weaken the flame retardancy of PolyFR because of the ability to absorb hydrogen bromide ( $\mathrm{HBr}$ ). Flame-retardant polystyrene (PS) was prepared via mixing PolyFR/BDDP/HT and then introducing inorganic particles such as antimonous oxide $\left(\mathrm{Sb}_{2} \mathrm{O}_{3}\right)$, organo montmorillonite (OMMT) and graphite to study their effect on the PolyFR/BDDP/HT system. The PS foams were prepared by batch foaming of the PS composites. Meanwhile, the combustion properties of PS composites and PS composite foams were characterized by limiting oxygen index (LOI) and vertical flame test (UL-94). The results indicated that the 2.5\%PolyFR/ 2.5\%BDDP/0.15\%HT/PS composite possessed $25.7 \% \mathrm{LOI}$ and pass UL-94 V-2 rating, while its foam possessed $30.7 \% \mathrm{LOI}$ and pass UL-94 $\mathrm{V}-2$ rating. And the addition of $\mathrm{Sb}_{2} \mathrm{O}_{3}, \mathrm{OMMT}$ and graphite reduced the oxygen index and vertical burning performance of PS composites and PS composite foams to different degrees. Otherwise, the flame-retardant (FR) mechanism of each FR system was studied by TGA and cone calorimetry. This revealed that PolyFR/BDDP promoted decomposition and dripping of PS early to remove heat through droplets and released $\mathrm{HBr}$ to quench free radicals and dilute combustible gas and oxygen during combustion. These properties of PolyFR/BDDP helped reduce the burning intensity and extinguish the flame through droplets, thereby endowing PS and its foam with better fireresistant properties. When the addition of $\mathrm{Sb}_{2} \mathrm{O}_{3}, \mathrm{OMMT}$ or graphite improved the thermal stability of PS, they weakened the droplet effect as well. Besides, PS foams were characterized by scanning electron microscopy (SEM). The results indicated PolyFR played an efficient heterogeneous cell nucleation role in the foaming process to reduce average cell size (from $110.5 \mu \mathrm{m}$ to $38.4 \mu \mathrm{m}$ ) and narrow cell distribution (from $60-160 \mu \mathrm{m}$ to $20-60 \mu \mathrm{m}$ ).
\end{abstract}

\section{Introduction}

Polystyrene foams, as the second largest segment of the foam market, have been widely used in many applications in the field of thermal insulation because of their outstanding thermal insulation properties and compressive strength. ${ }^{1-6}$ But PS foam is an extremely flammable material; the LOI value of PS foam is only about $18 \%$ and has no UL-94 rating. ${ }^{7}$ Therefore, research on flame-retardant PS foam is necessary. Hexabromocyclododecane (HBCD), a traditional flame retardant of polystyrene foam, which can endow PS with excellent flame-

${ }^{a}$ School of Materials and Mechanical Engineering, Beijing Technology and Business University, Beijing 100048, People's Republic of China. E-mail: wangxid@th.btbu. edu.cn; xinfei@th.btbu.edu.cn; Tel: +86 106898 3954; +86 1068985531

${ }^{b}$ Beijing Key Laboratory of Quality Evaluation Technology for Hygiene and Safety of Plastics, Beijing 100048, People's Republic of China retardant performance at a typical loading between 0.8 and 4.0 wt $\%$ (ref. 8) has been identified to be a kind of PBT (persistence, bioaccumulation, toxicity) substance and would be gradually replaced on a global scale. ${ }^{9-11}$

In recent years, many kinds of non-halogen and halogen flame retardant PS composites had been studied., ${ }^{\mathbf{8} 12}$ Some systems had been applied to flame retardant PS and PS foam, such as nitrogen phosphorus flame retardants and intumescent flame retardants. ${ }^{7,13-18}$ Besides organic flame-retardant additives, inorganic flame-retardant additives including layered double hydroxide of zinc aluminum and zinc magnesium ${ }^{19}$ carbon nanotubes ${ }^{20}$ and nanoclays, ${ }^{21-23}$ can also effectively reinforce flame-retardant properties of PS and PS foam. But in order to attain outstanding flame-retardant properties, the content of flame retardants is usually more than $20 \mathrm{wt} \% .^{\mathbf{8 , 2 4}}$ However, such a large amount of flame retardants addition will have an adverse effect on the foaming properties of PS. ${ }^{8}$ As for 


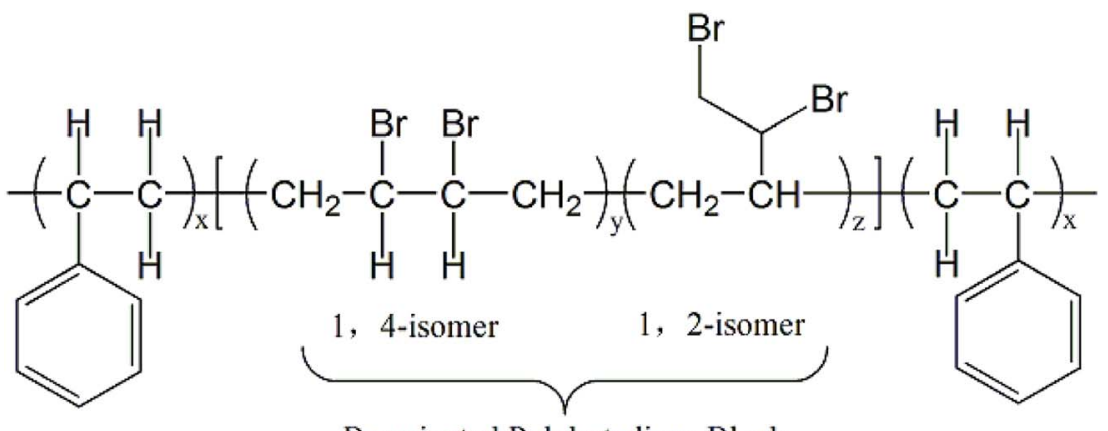

Brominated Polybutadiene Block

Scheme 1 Chemical structure of PolyFR.

halogen flame retardants, such as brominated polystyrene (BPS), decabromodiphenyl ethane (DBDPE) and tetrabromobisphenol A bis (2,3-dibromopropyl)ether (BDDP) with $\mathrm{Sb}_{2} \mathrm{O}_{3}$ which may be environmentally friendly brominated flame retardants for no production of dioxin during burning and have been commercialized were also studied ${ }^{25-29}$ However, at least $10 \mathrm{wt} \%$ of BPS, DBDPE or BDDP should be mixed with PS or PS foam to acquire excellent flame retardancy. ${ }^{27-29}$ Therefore, the flame retardants which has high efficiency and low addition still need to be researched for meeting requirements for foaming properties. Recently, as in Scheme 1 a kind of brominated polymer flame retardant (PolyFR) which exhibits better environmental friendliness than that of HBCD was reported, ${ }^{30-32}$ in which only 3-5 wt\% PolyFR in PS or PS foam can exert excellent flame-retardant effect. ${ }^{33}$

Mark W. Beach has studied on the mechanism of flame retardant of PolyFR and found that PolyFR has the similar flame retardant mechanism to HBCD in PS blends where both produce hydrogen bromide ( $\mathrm{HBr}$ ) to exert flame retardant effect in gas phase and both produce enhanced degradation of polymers as another important way to exert flame retardant effect in condensed phase..$^{33-36}$ It can also be fined tuned to provide very good thermal stability where a higher level of brominated 1,2 units (relative to 1,4 units) in the polybutadiene portion provides better thermal stability. Addition of the styrene blocks to form the triblock structure gives a more compatible interface and many smaller domains. ${ }^{33}$ This increases the interface of dispersed phase which intends to lead to better cell morphology. What's more, PolyFR was an environmentally sustainable alternative to HBCD which has been demonstrated by the environmental health and safety (EH\&S) evaluation. ${ }^{30}$ The physical chemical properties of PolyFR, namely its high molecular weight, indicated it would possess very low bioavailability and intrinsic toxicity. The results of the environmental fate and ecological toxicity testing demonstrated that PolyFR does not pose the health and environmental issues, such as bioaccumulation and toxicity, which are associated with HBCD. ${ }^{30}$

As a new flame retardant, PolyFR is environment-friendly, there are few reports about the effect of combination of PolyFR and other flame-retardant additives in PS or PS foams. So it is necessary for PolyFR to blend with other flame retardants additives to study their combined action. Besides, the study may reduce the costs. In addition, PolyFR would degrade in the process of blending PolyFR with PS in the torque rheometer and twin-screw extruder. Therefore, an efficient heat stabilizer is needed for PolyFR to adapt to different processing conditions.

In this paper, the flame-retardant PS composites and their foams were prepared via blending the flame-retardant PolyFR/ BDDP with PS. Furthermore, the flame retardancy of PS composites and their foams were researched; the FR mechanism of PolyFR/BDDP was also illuminated. Besides, HT as heat stabilizer to PolyFR was used in flame-retardant system. At the same time, the effect of $\mathrm{Sb}_{2} \mathrm{O}_{3}$, OMMT and graphite on PolyFR/ $\mathrm{BDDP} / \mathrm{HT}$ system was studied.

\section{Experimental}

\subsection{Materials}

(1) Polystyrene (158 K) was purchased from BASF-YPC Co., Ltd; (2) brominated polybutadiene-polystyrene (PolyFR-122P) which has a typical $65 \%$ bromine content was purchased from Bromine Compounds Limited; (3) tetrabromobisphenol A bis (2,3-dibromopropyl)ether (HT-107) was purchased from Jinan Taixing Fine Chemicals Co., Ltd; (4) organo montmorillonite (DK1) was purchased from Zhejiang Fenghong New Material Co., Ltd; (5) graphite (S1) was purchased from Qingdao Ruisheng Graphite Co., Ltd.; (6) hydrotalcite (HYCITE®713) was purchased from Kelaien Chemical Co., Ltd; and (7) antimonous oxide was purchased from Sinopharm Chemical Reagent Co., Ltd.

Table 1 Abbreviations and acronyms in the article

\begin{tabular}{ll}
\hline Full name & Abbreviations \\
\hline Polystyrene & PS \\
Hydrotalcite & $\mathrm{HT}$ \\
PolyFR & $\mathrm{P}$ \\
$\mathrm{BDDP}$ & $\mathrm{B}$ \\
$\mathrm{Sb}_{2} \mathrm{O}_{3}$ & $\mathrm{~S}$ \\
OMMT & $\mathrm{O}$ \\
Graphite & $\mathrm{G}$
\end{tabular}


Table 2 Formulas of mixed powder

\begin{tabular}{lcc}
\hline Sample & PolyFR (wt $\%)$ & HT (wt $\%)$ \\
\hline PolyFR & 100 & 0 \\
HT5\%/PolyFR & 95 & 5 \\
HT10\%/PolyFR & 90 & 10
\end{tabular}

Table 3 Formulas of flame-retardant PS composites

\begin{tabular}{llll}
\hline Sample & PS (wt\%) & PolyFR (wt\%) & HT (wt\%) \\
\hline P/PS & 95 & 5 & - \\
HT0.05\%/P/PS & 94.95 & 5 & 0.05 \\
HT0.15\%/P/PS & 94.85 & 5 & 0.15 \\
HT0.25\%/P/PS & 94.75 & 5 & 0.25 \\
HT0.35\%/P/PS & 94.65 & 5 & 0.35 \\
HT0.45\%/P/PS & 94.55 & 5 & 0.45 \\
HT0.55\%/P/PS & 94.45 & 5 & 0.55 \\
HT0.65\%/P/PS & 94.35 & 5 & 0.65 \\
HT0.75\%/P/PS & 94.25 & 5 & 0.75 \\
HT0.85\%/P/PS & 94.15 & 5 & 0.85 \\
HT0.95\%/P/PS & 94.05 & 5 & 0.95 \\
HT1.05\%/P/PS & 93.95 & 5 & 1.05
\end{tabular}

\subsection{Sample preparation}

In order to investigate thermal stabilization of HT on PolyFR, mixed powder was prepared by mixing and grinding PolyFR and HT with various weight ratios, the formulas were presented in Table 2. The FR PS composites were prepared via mixing PolyFR and HT into PS with different mass ratios. PS, PolyFR and HT were blended by torque rheometer at $190{ }^{\circ} \mathrm{C}$ for $10 \mathrm{~min}$. (In the process of extrusion foaming, flame retardants will be heated to melt about $10 \mathrm{~min}$ at $190{ }^{\circ} \mathrm{C}$.) Then, the flame-retardant PS composites were compressed to the required sheets with standard dimensions in the mold. The formulas were presented in Table 3. The PolyFR/BDDP/HT mixed $\mathrm{Sb}_{2} \mathrm{O}_{3}$, OMMT or graphite were blended into PS to prepare FR PS composites by the same process, the formulas were presented in Table 4 . Some abbreviations and acronyms in the article were listed in Table 1.

\subsection{Batch foaming}

Batch foaming method was applied to prepare the FR PS composite foams in autoclave and $\mathrm{sc}-\mathrm{CO}_{2}$ was used as physical

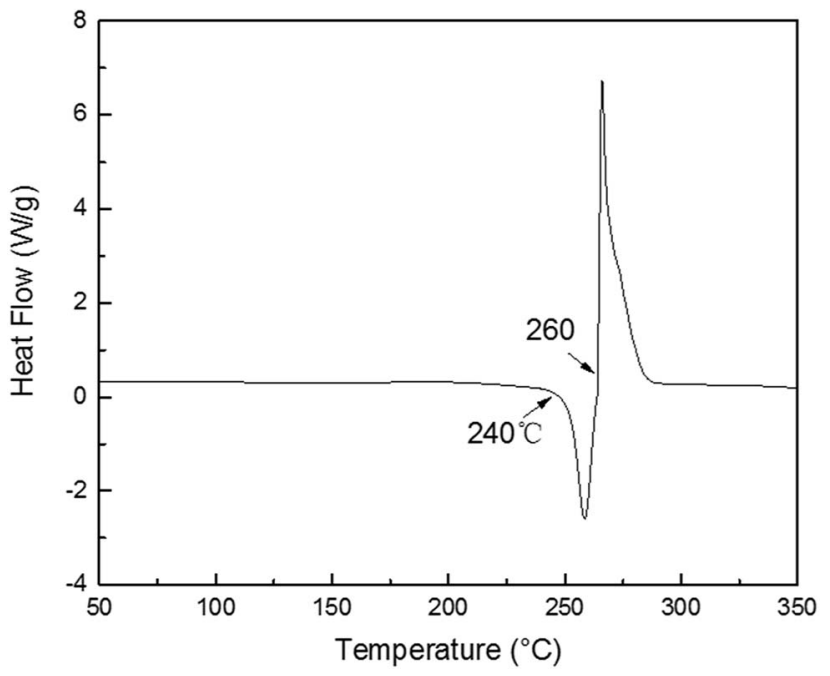

Fig. 1 DSC curve of PolyFR.

blowing agent. All of foams were prepared under the same condition to research the discrepancies of foaming behaviors for PS composites. First, the FR PS composites were placed in the autoclave at $130{ }^{\circ} \mathrm{C}$ and $12 \mathrm{MPa}$ for $3 \mathrm{~h}$ to saturation. After the $\mathrm{CO}_{2}$ got adequate saturation in the PS melt, an instant pressure drop was exerted on the samples by discharge of $\mathrm{CO}_{2}$ to ambient pressure at even pressure drop rate of $3 \mathrm{MPa} \mathrm{s}^{-1}$. At last, the FR PS composite foams were shaped for further characterization.

\subsection{Characterizations}

2.4.1. Thermogravimetric analysis (TGA). TGA was performed using TA instrument Q5000 IR TGA (TA Instruments, NewCastle, DE, USA) under $\mathrm{N}_{2}$ atmosphere. The samples were heated from $50{ }^{\circ} \mathrm{C}$ to 500 or $600{ }^{\circ} \mathrm{C}$ at a heating rate of $10{ }^{\circ} \mathrm{C} \min ^{-1}$. For mixed powders, the samples also were heated from $50{ }^{\circ} \mathrm{C}$ to $240{ }^{\circ} \mathrm{C}$ at a heating rate of $30{ }^{\circ} \mathrm{C} \mathrm{min}{ }^{-1}$ and kept for $20 \mathrm{~min}$.

2.4.2. Limiting oxygen index (LOI). The LOI values were measured using Dynisco LOI instrument (FTT, UK) based on the American Society for Testing and Materials ASTM D2863-97, and the sheet dimensions were $125.0 \times 6.5 \times 3.2 \mathrm{~mm}$. For

Table 4 Formulas of flame-retardant PS composites

\begin{tabular}{|c|c|c|c|c|c|c|c|}
\hline Sample & PS (wt $\%)$ & PolyFR (wt\%) & BDDP (wt\%) & HT (wt\%) & $\mathrm{Sb}_{2} \mathrm{O}_{3}(\mathrm{wt} \%)$ & OMMT (wt\%) & Graphite (wt\%) \\
\hline PS & 100 & - & - & - & - & - & - \\
\hline P5\%/HT/PS & - & 5 & & 0.15 & - & - & - \\
\hline $\mathrm{P} 3.5 \% / \mathrm{B} 1.5 \% / \mathrm{HT} / \mathrm{PS}$ & - & 3.5 & 1.5 & 0.15 & - & - & - \\
\hline $\mathrm{P} 2.5 \% / \mathrm{B} 2.5 \% / \mathrm{HT} / \mathrm{PS}$ & - & 2.5 & 2.5 & 0.15 & - & - & - \\
\hline $\mathrm{P} 1.5 \% / \mathrm{B} 3.5 \% / \mathrm{HT} / \mathrm{PS}$ & - & 1.5 & 3.5 & 0.15 & - & - & - \\
\hline $\mathrm{P} 2.5 \% / \mathrm{B} 2.5 \% / \mathrm{S} 0.8 \% / \mathrm{HT} / \mathrm{PS}$ & - & 2.5 & 2.5 & 0.15 & 0.8 & - & - \\
\hline $\mathrm{P} 2.5 \% / \mathrm{B} 2.5 \% / \mathrm{S} 1.6 \% / \mathrm{HT} / \mathrm{PS}$ & - & 2.5 & 2.5 & 0.15 & 1.6 & - & - \\
\hline P2.5\%/B2.5\%/O1\%/HT/PS & - & 2.5 & 2.5 & 0.15 & - & 1 & - \\
\hline $\mathrm{P} 2.5 \% / \mathrm{B} 2.5 \% / \mathrm{O} 2 \% / \mathrm{HT} / \mathrm{PS}$ & - & 2.5 & 2.5 & 0.15 & - & 2 & - \\
\hline $\mathrm{P} 2.5 \% / \mathrm{B} 2.5 \% / \mathrm{G} 1 \% / \mathrm{HT} / \mathrm{PS}$ & - & 2.5 & 2.5 & 0.15 & & - & 1 \\
\hline $\mathrm{P} 2.5 \% / \mathrm{B} 2.5 \% / \mathrm{G} 2 \% / \mathrm{HT} / \mathrm{PS}$ & - & 2.5 & 2.5 & 0.15 & & - & 2 \\
\hline
\end{tabular}


Table 5 TGA and DTG data of PolyFR with various HT contents

\begin{tabular}{lccc}
\hline Sample & PolyFR & HT5\%/PolyFR & HT10\%/PolyFR \\
\hline Onset degradation temperature ${ }^{a}\left({ }^{\circ} \mathrm{C}\right)$ & 265.1 & 271.3 & 274.1 \\
Temperature of peak decomposition rate $\left({ }^{\circ} \mathrm{C}\right)$ & 273.9 & 283.1 & 288.1 \\
Maximum decomposition rate $\left(\%{ }^{\circ} \mathrm{C}\right)$ & 3.59 & 2.46 & 2.21 \\
${ }^{a}$ The temperature which decomposition of samples reached $5 \%$. & &
\end{tabular}

Table 6 TGA and DTG data of PolyFR with various HT contents

\begin{tabular}{lccc}
\hline Sample & PolyFR & HT5\%/PolyFR & HT10\%/PolyFR \\
\hline Maximum decomposition $(\%)$ & 50.6 & 19.3 & 17.2 \\
Maximum decomposition rate $\left(\% \mathrm{~min}^{-1}\right)$ & 6.36 & 1.55 & 1.49
\end{tabular}

foaming samples, the dimensions were $125 \times 10 \times 10 \mathrm{~mm}$. Three tests for each sample were repeated to make sure error value was in $\pm 0.5 \%$.

2.4.3. The vertical burning test (UL94). The UL94 was performed using FTT0082 instrument based on the ASTM D3801 testing method, and the sheet dimensions were $125 \times 12.7 \times$ $3.2 \mathrm{~mm}$. For foaming samples the foam dimensions were $130 \times$ $13 \times 13 \mathrm{~mm}$. (Batch foaming limited the size of the samples, so the ASTM D3801 test method was chosen to observe the combustion performance of the foam samples.)

2.4.4. Scanning electron microscopy (SEM). The dispersion morphology and the cell morphology of PS composite foam samples were characterized using a scanning electron microscope (SEM, TESCAN YEGA II, TESCAN s.r.o) at an acceleration voltage of $10 \mathrm{kV}$. The cell morphology of PS composite foam samples was observed under the magnification of $800 \times$. Imagepro plus 6.0 was used to bubble data statistics and then the data were introduced into the equations: ${ }^{37}$

$$
\begin{gathered}
N_{\mathrm{c}}=\left(\frac{n}{A}\right)^{3 / 2} \varphi \\
\varphi=\frac{\rho_{\mathrm{u}}}{\rho_{\mathrm{f}}}
\end{gathered}
$$

where $N_{\mathrm{c}}$ is cell density (cells per $\mathrm{cm}^{3}$ ), $n$ is cell numbers accounted in the statistical areas, $A$ is the statistical areas $\left(\mathrm{cm}^{2}\right)$ in which accounting for cell numbers, $\varphi$ is the foaming expansion ratio of polymer, $\rho_{\mathrm{f}}$ is the density of foam $\left(\mathrm{g} \mathrm{cm}^{-3}\right), \rho_{\mathrm{u}}$ is the density of polymer $\left(\mathrm{g} \mathrm{cm}^{-3}\right)$. The density of PS composite foam samples were obtained through a density tester (Ultra Pyc actual density tester, Quanta chrome, America).

\section{Results and discussion}

\subsection{Thermal stability of PolyFR}

TGA curves of PolyFR shown in Fig. 2 indicated that its initial degradation (0.5\% mass loss) temperature was about $243.1{ }^{\circ} \mathrm{C}$. From DSC curve of PolyFR in Fig. 1, there was no obvious peaks in DSC observed before $240{ }^{\circ} \mathrm{C}$ indicating that no obvious crosslinking that could be caused by leftover double bonds from the PB occurred before degradation of PolyFR. The endothermic peak began to appear when the temperature reached $240{ }^{\circ} \mathrm{C}$ indicating that PolyFR began to decompose and release $\mathrm{HBr}$ when the temperature reached $240{ }^{\circ} \mathrm{C}$. The similar result was observed in the TGA curve of PolyFR. The exothermic peak began to appear when the temperature reached $260{ }^{\circ} \mathrm{C}$ indicating that crosslinking did happen in the process of PolyFR degradation. The color of sample P5\%/PS without HT had turned black after blending in a torque rheometer at $190{ }^{\circ} \mathrm{C}$ for 10 min shown in Table 7. This showed that PolyFR had been decomposed in this processing condition without any thermal stabilizer. The result was different from what we got from the TGA analysis curves of PolyFR in Fig. 2, in which the initial decomposing temperature was $243.1{ }^{\circ} \mathrm{C}$ more than the actual processing temperature. This was due to PolyFR would be affected by shear stress and thermal oxidative degradation in practice compared to TG test. So we used HT as the thermal stabilizer for PolyFR in the subsequent experiments.

\subsection{Thermal stabilization of HT on PolyFR}

In order to testify thermal stabilization of HT on PolyFR, TGA of PolyFR and HT mixed powders were tested. Their TGA curves under $\mathrm{N}_{2}$ atmosphere were shown in Fig. 2 and Table 5.

Table 7 The colors of samples with various HT contents

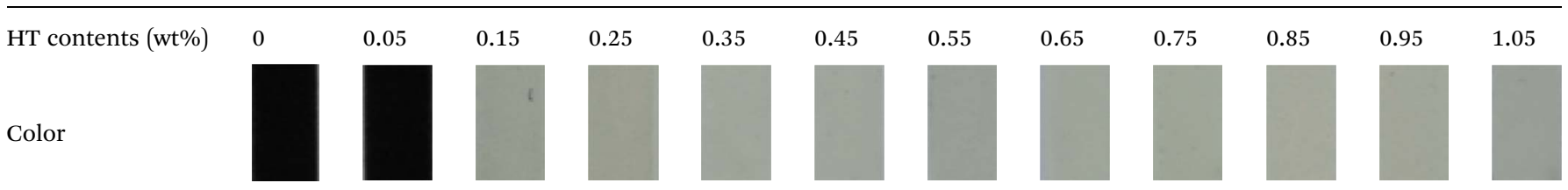




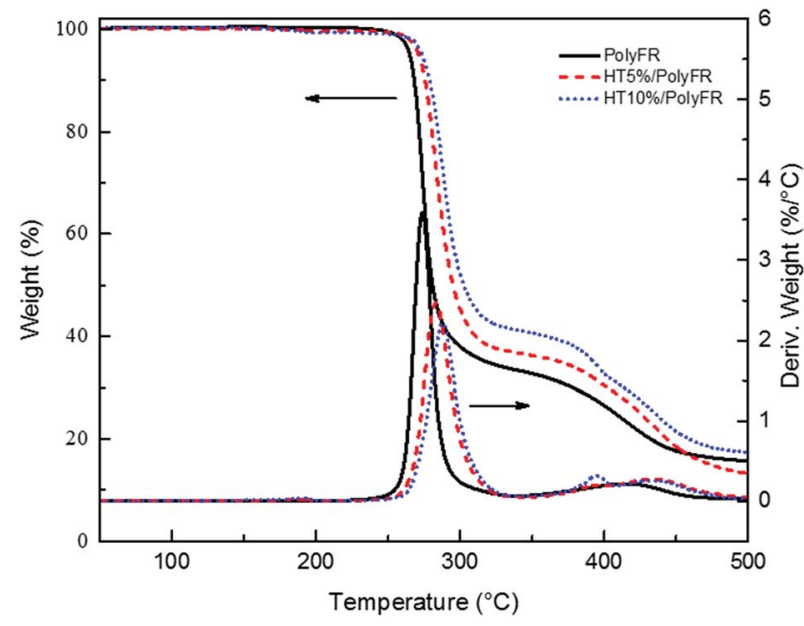

Fig. 2 TGA and DTG curves of PolyFR with various HT contents.

As shown in Fig. 2 and Table 5, when the samples were heated from $50{ }^{\circ} \mathrm{C}$ to $500{ }^{\circ} \mathrm{C}$ at a heating rate of $10{ }^{\circ} \mathrm{C} \mathrm{min}-1$, PolyFR with $5 \%$ or $10 \%$ HT had the higher onset decomposing temperature and lower maximum decomposing rate than pure PolyFR powder. The acid production $\mathrm{HBr}$ from decomposed PolyFR may promote the early degradation of PolyFR like the autocatalytic degradation of the polyvinylchloride because of the similar structure. ${ }^{38-40} \mathrm{HT}$ as a kind of acid absorber has the basic properties that make it possible to absorb $\mathrm{HBr}$ formed during thermal dehydrobromination of PolyFR, and thus inhibit the degradation of the PolyFR. ${ }^{41-43}$

As shown in Fig. 3 and Table 6, the samples were heated from $50{ }^{\circ} \mathrm{C}$ to $240{ }^{\circ} \mathrm{C}$ at a heating rate of $30^{\circ} \mathrm{C} \mathrm{min}{ }^{-1}$ and kept for $20 \mathrm{~min}$. Pure PolyFR decomposing rate and decomposing amount increased sharply starting from 13th minute. When incorporating $5 \%$ HT to pure PolyFR, the maximum decomposing rate of mixed powder was decreased from $6.36 \% \mathrm{~min}^{-1}$ to $1.55 \% \mathrm{~min}^{-1}$ and the decomposing amount from $50.6 \%$ to $19.3 \%$. It was further evidence the thermal stabilization of HT on PolyFR was remarkable. But when HT content was increased

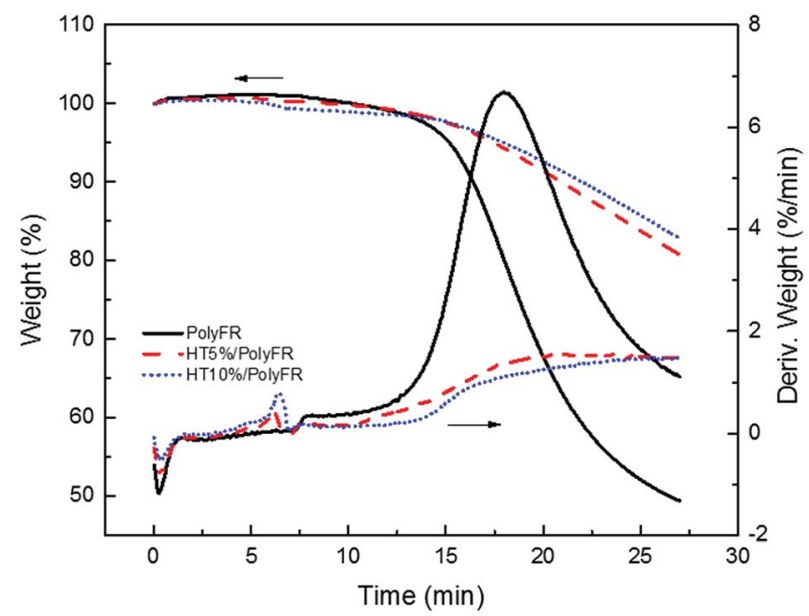

Fig. 3 TGA and DTG curves of PolyFR with various HT contents.

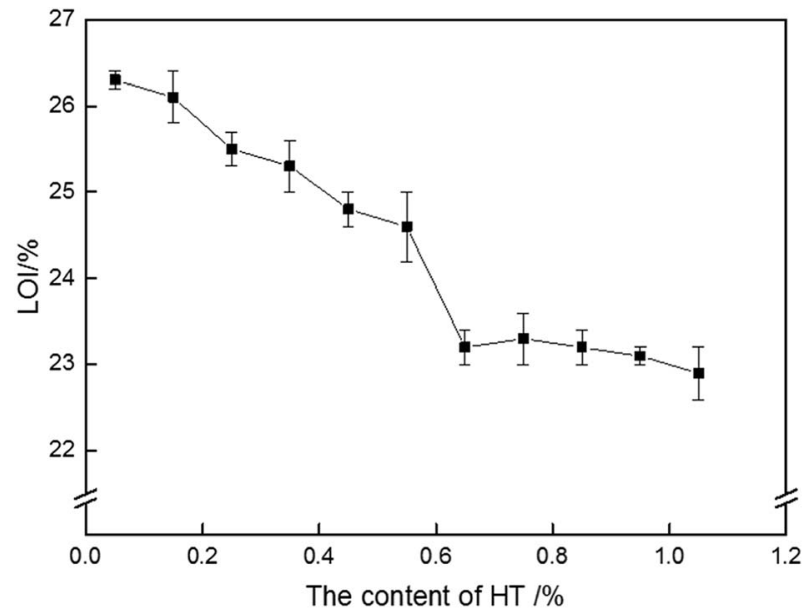

Fig. 4 LOI curve of P/PS composites with various HT contents.

to $10 \%$, the effect didn't have an obvious improvement. Because 5\% HT may absorb most $\mathrm{HBr}$ formed during thermal dehydrobromination of PolyFR, excessive HT won't obviously improve the thermal stability of PolyFR.

To explore the thermal stabilization of HT on PolyFR in practice, the colors of samples were listed in Table 7 . The colors of P/PS and $\mathrm{HT} 0.05 \% / \mathrm{P} / \mathrm{PS}$ are black, because the content of HT in the samples is not enough to absorb most $\mathrm{HBr}$ formed during thermal dehydrobromination of PolyFR to inhibit the autocatalytic degradation of PolyFR which leading to their severe degradation. The radicals from degradation of PolyFR enhanced the chain scission of PS which contained tertiary carbon atoms in the backbone more easily. ${ }^{33,36}$ With the increase of the HT content, the degradation of PolyFR was weakened and the colors of samples with more than $0.15 \%$ HT turned into white.

\subsection{Effect of HT on flame retardancy of PolyFR}

To explore the effect of HT on the flame retardancy of PolyFR, the LOI values of samples were carried out in Fig. 4. LOI values of PS composites were gradually decreased with the increase of HT content. Because PolyFR releases HBr in the gas phase after degradation. The $\mathrm{HBr}$ molecule acts as a radical scavenger of radicals $(\mathrm{OH}, \mathrm{H})$ to availably extinguish the flame..$^{28,33,44}$ As was stated above, $\mathrm{HBr}$ released by PolyFR in combustion process would be absorbed by HT leading to HBr didn't work effectively.

The addition amount of HT should be as little as possible but on the promise that PolyFR won't degrade severely during processing. By analyzing Fig. 4 and Table 7, the conclusion was that the addition amount of HT should be $0.15 \%$ at most for $5 \%$ PolyFR. For convenience of analysis, the content of HT in the following study is $0.15 \%$.

\subsection{Flame-retardant properties of PS with different PolyFR/ BDDP}

Fire performance data for composites and foams were listed in Tables 8 and 9. Compared with the data from Tables 8 and 9, the 
Table 8 LOI value and UL94 rating of PS and its composites

\begin{tabular}{|c|c|c|c|c|c|c|}
\hline Sample (resin) & LOI\% & av-t1 (s) & av-t2 (s) & Dripping & Ignition & UL94 rating \\
\hline PS & $17.5 \pm 0.3$ & $>30$ & $>30$ & Yes & Yes & Unrated \\
\hline P5\%/HT/PS & $26.8 \pm 0.1$ & 0.5 & 0.4 & Yes & Yes & V-2 \\
\hline $\mathrm{P} 2.5 \% / \mathrm{B} 2.5 \% / \mathrm{HT} / \mathrm{PS}$ & $25.7 \pm 0.2$ & 0.4 & 0.4 & Yes & Yes & $\mathrm{V}-2$ \\
\hline $\mathrm{P} 1.5 \% / \mathrm{B} 3.5 \% / \mathrm{HT} / \mathrm{PS}$ & $24.5 \pm 0.1$ & 0.3 & 0.2 & Yes & Yes & $\mathrm{V}-2$ \\
\hline
\end{tabular}

Table 9 LOI value and UL94 rating of PS foam and its composite foams

\begin{tabular}{|c|c|c|c|c|c|c|}
\hline Sample (foam) & LOI\% & av-t1 (s) & av-t2 (s) & Dripping & Ignition & UL94 rating \\
\hline PS & $18.1 \pm 0.3$ & $>30$ & $>30$ & Yes & Yes & Unrated \\
\hline P5\%/HT/PS & $32.1 \pm 0.3$ & 0.4 & 0.3 & Yes & Yes & $\mathrm{V}-2$ \\
\hline $\mathrm{P} 2.5 \% / \mathrm{B} 2.5 \% / \mathrm{HT} / \mathrm{PS}$ & $30.7 \pm 0.4$ & 0.8 & 0.3 & Yes & Yes & $\mathrm{V}-2$ \\
\hline P1.5\%/B3.5\%/HT/PS & $28.8 \pm 0.2$ & 0.9 & 0.2 & Yes & Yes & $\mathrm{V}-2$ \\
\hline
\end{tabular}

LOI value of neat PS is $17.5 \%$ and its foam is $18.1 \%$. They all cannot pass UL94 test. After PolyFR/BDDP/HT were incorporated into PS, the flame-retardant properties of PS composites were gradually enhanced. When 5\% PolyFR was blended into PS, the LOI value of PS composite was increased from $17.5 \%$ to $26.8 \%$, and the UL94 test reached V-2 rating with a shorter combustion time. Corresponding to the PS composite, the LOI value of its foam was also increased from $18.1 \%$ to $32.1 \%$, and the UL94 test reached V-2 rating. PolyFR endowed PS with better flame retardancy. With the increase of BDDP content and the decrease of PolyFR content the LOI values of PS composites and their foams decreased gradually. BDDP, a mixed aliphatic/ aromatic bromine compound, has the better thermal stability than PolyFR, because aromatic bromine has the better thermal stability than aliphatic bromine as the TGA curves of BDDP and PolyFR shown in Fig. 5. In the process of combustion aromatic bromine released $\mathrm{HBr}$ later than aliphatic bromine, leading to aromatic bromine had the worse FR performance than aliphatic bromine.

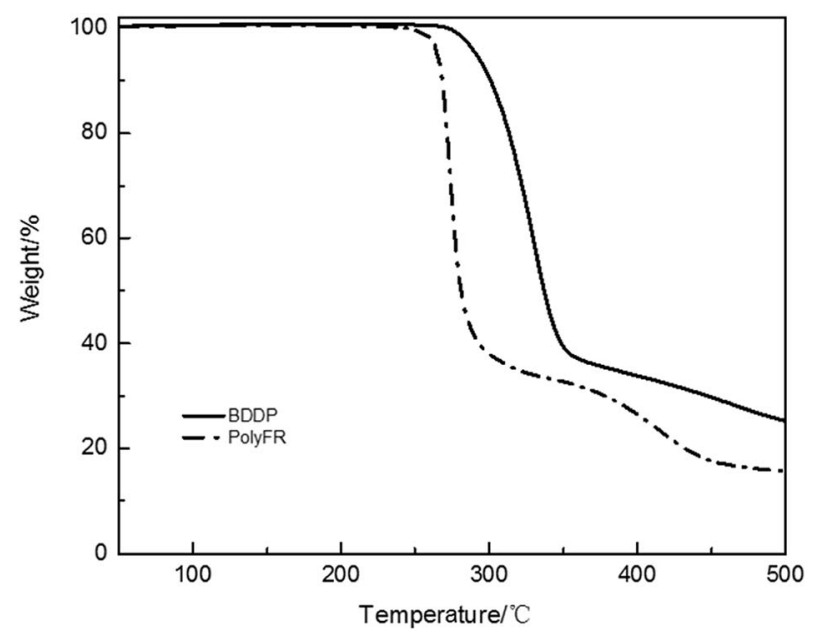

Fig. 5 TGA curves of BDDP and PolyFR.
The curves of heat release rate (HRR) tested by cone calorimetry were shown in Fig. 6, and the relevant data were listed in Table 10. Actually, the heat took away by molten droplets in LOI and UL94 test led to incomplete combustion of PS composites, which resulted in a better flame retardant effect in these tests. However, in cone calorimetry test, molten resin was decomposed and burned in a limited space. ${ }^{45}$ Therefore, PolyFR/BDDP would exhibit a more obvious effect in the LOI and UL94 test than in the cone calorimetry test. Nevertheless, we still derived some properties of PolyFR/BDDP from these data.

After addition of flame retardants, PS composites reached peak of HRR (pk-HRR) values faster than pure PS and pk-HRR values was higher than pure PS. There are two reasons. First, in the cone calorimetry test, the samples were placed in the fixed container, and the molten resin would be continuously degraded in the container, and the heat was not taken away in time by the droplets, thus a higher peak would be produced. Second, the inducing degradation effect on PS of PolyFR/BDDP produced combustible gas faster leading to concentrated heat release during the combustion process. Although the pk-HRR

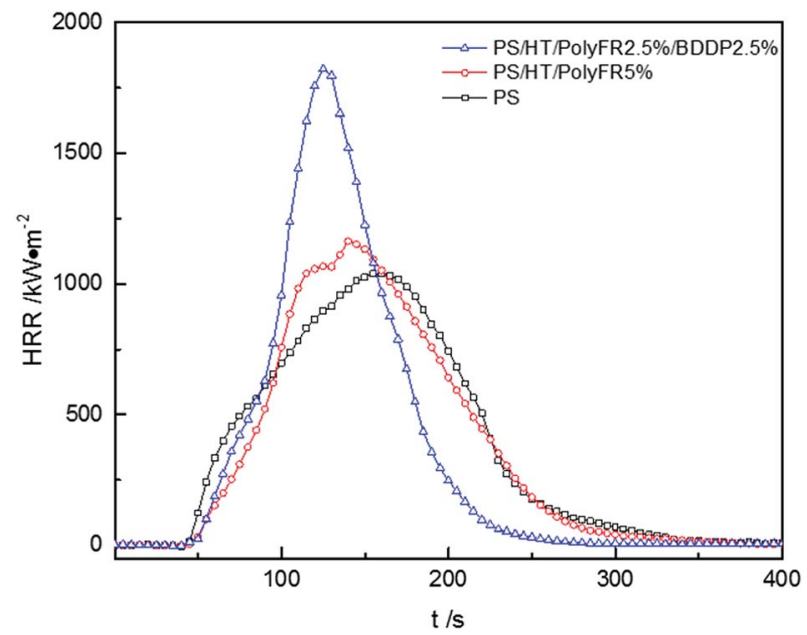

Fig. 6 Heat release rate (HRR) curves of PS composites. 
Table 10 The data of PS composites from cone calorimetry test

\begin{tabular}{llllll}
\hline Sample & pk-HRR $\left(\mathrm{kW} \mathrm{m}^{-2}\right)$ & THR $\left(\mathrm{MJ} \mathrm{m}^{-2}\right)$ & av-EHC $\left(\mathrm{MJ} \mathrm{kg}^{-1}\right)$ & ${\mathrm{av-COY}\left(\mathrm{kg} \mathrm{kg}^{-1}\right)}^{\mathrm{av}-\mathrm{CO}_{2} \mathrm{Y}\left(\mathrm{kg} \mathrm{kg}^{-1}\right)}$ \\
\hline PS & 1040 & 146.2 & 33.6 & 0.0197 & 2.901 \\
P5\%/HT/PS & 1163 & 141.8 & 34.9 & 0.114 & 2.564 \\
P2.5\%/B2.5\%/HT/PS & 1821 & 139.9 & 35.9 & 0.139 & 2.944 \\
& & & &
\end{tabular}

Table 11 LOI value and UL94 rating of PS composites

\begin{tabular}{|c|c|c|c|c|c|c|}
\hline $\mathrm{P} 2.5 \% / \mathrm{B} 2.5 \% / \mathrm{HT} / \mathrm{PS}$ & $25.7 \pm 0.2$ & 0.4 & 0.4 & Yes & Yes & $\mathrm{V}-2$ \\
\hline $\mathrm{P} 2.5 \% / \mathrm{B} 2.5 \% / \mathrm{S} 0.8 \% / \mathrm{HT} / \mathrm{PS}$ & $25 \pm 0.3$ & 1.4 & 0.9 & Yes & Yes & $\mathrm{V}-2$ \\
\hline
\end{tabular}

Table 12 LOI value and UL94 rating of PS composite foams

\begin{tabular}{|c|c|c|c|c|c|c|}
\hline Sample (foam) & LOI\% & av-t1 (s) & av-t2 (s) & Dripping & Ignition & UL94 rating \\
\hline $\mathrm{P} 2.5 \% / \mathrm{B} 2.5 \% / \mathrm{HT} / \mathrm{PS}$ & $30.7 \pm 0.4$ & 0.8 & 0.3 & Yes & Yes & $\mathrm{V}-2$ \\
\hline $\mathrm{P} 2.5 \% / \mathrm{B} 2.5 \% / \mathrm{S} 0.83 \% / \mathrm{HT} / \mathrm{PS}$ & $30.8 \pm 0.2$ & 0.5 & 0.5 & Yes & Yes & $\mathrm{V}-2$ \\
\hline
\end{tabular}

values of PS composites increased, the values of THR decreased. After replacing 50\% PolyFR with BDDP, pk-HRR value caused by burning intensity increased. As mentioned above, the bromine free radical from BDDP didn't quench free radicals of combustion effectively as PolyFR since aromatic bromine had the better thermal stability than aliphatic bromine. According to the outcome from $\mathrm{P} 5 \% / \mathrm{HT} / \mathrm{PS}$ or $\mathrm{P} 2.5 \% / \mathrm{B} 2.5 \% / \mathrm{HT} / \mathrm{PS}$ in Table 10, addition of PolyFR and PolyFR/BDDP decreased the total heat release (THR) values compared with pure PS, indicating that PolyFR and BDDP played a better flame-retardant effect in gas phase and led to more incomplete combustion. ${ }^{46}$ The average of carbon oxide yields (av-COY) and the average of carbon dioxide yields $\left(\mathrm{av}-\mathrm{CO}_{2} \mathrm{Y}\right)$ values of samples were listed in Table 10. The av-COY values of all samples increased compared

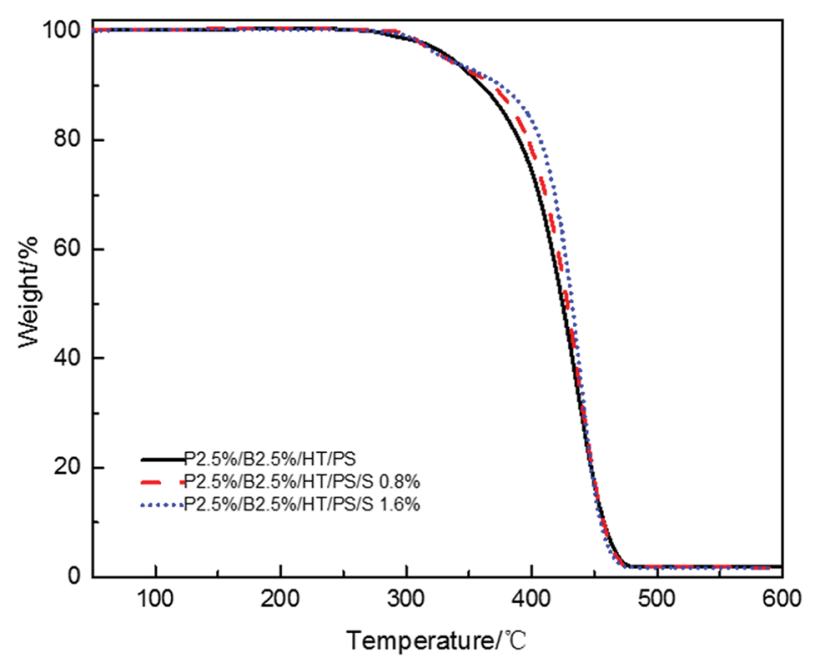

Fig. 7 TGA curves of FR PS composites with various $\mathrm{Sb}_{2} \mathrm{O}_{3}$ content. with pure PS. Meanwhile, av- $\mathrm{CO}_{2} \mathrm{Y}$ values had the reverse tendency. The results further confirmed that PolyFR and BDDP would availably inhibit radical chain reaction in burning process and cause incomplete combustion in gas phase. PS foam with $2.5 \%$ PolyFR and $2.5 \%$ BDDP still had LOI value of $30.7 \%$ and passed UL94 V-2 rating. On this basis, the synergy and antagonism of three kinds of inorganic particles on PolyFR/ BDDP/HT system was studied.

\subsection{Flame-retardant properties of PS with $\mathrm{Sb}_{2} \mathrm{O}_{3} /$ PolyFR/ BDDP/HT}

In order to research the effect of $\mathrm{Sb}_{2} \mathrm{O}_{3}$ on flame retardancy of PolyFR/BDDP/HT system, the $\mathrm{Sb}_{2} \mathrm{O}_{3}$ was incorporated into PolyFR/BDDP/HT/PS composites.

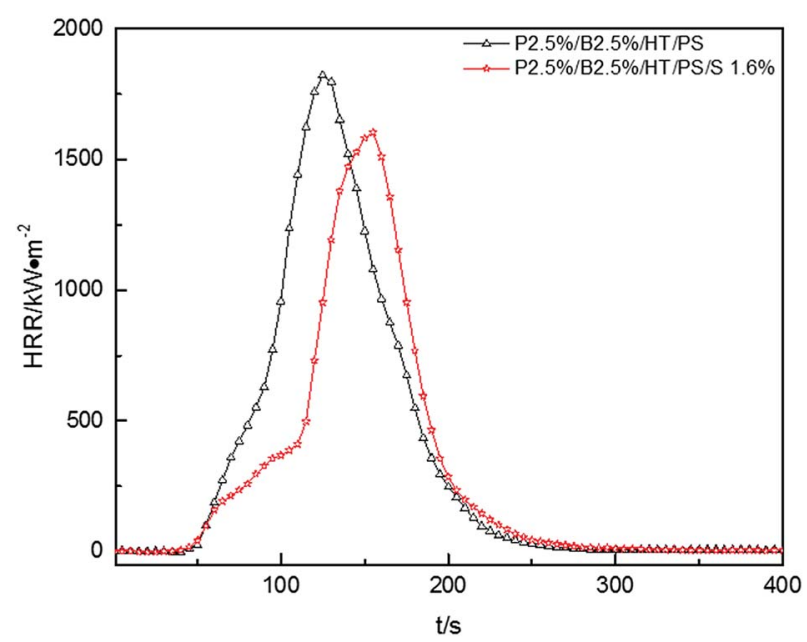

Fig. 8 Heat release rate (HRR) curves of PS composites. 
Table 13 The data of PS composites from cone calorimetry test

\begin{tabular}{llllll}
\hline Sample & pk-HRR $\left(\mathrm{kW} \mathrm{m}^{-2}\right)$ & THR $\left(\mathrm{MJ} \mathrm{m}^{-2}\right)$ & $\mathrm{av}-\mathrm{EHC}\left(\mathrm{MJ} \mathrm{kg}^{-1}\right)$ & ${\mathrm{av-COY}\left(\mathrm{kg} \mathrm{kg}^{-1}\right)}^{\mathrm{av}-\mathrm{CO}_{2} \mathrm{Y}\left(\mathrm{kg} \mathrm{kg}^{-1}\right)}$ \\
\hline P2.5\%/B2.5\%/S0.83\%/HT/PS & 1821 & 139.9 & 35.9 & 0.139 & 2.944 \\
P2.5\%/B2.5\%/S1.66\%/HT/PS & 1604 & 117.2 & 28.8 & 0.158 & 2.317
\end{tabular}

Table 14 LOI value and UL94 rating of PS composite foams

\begin{tabular}{|c|c|c|c|c|c|c|}
\hline P2.5\%/B2.5\%/HT/PS & $25.7 \pm 0.2$ & 0.4 & 0.4 & Yes & Yes & $\mathrm{V}-2$ \\
\hline $\mathrm{P} 2.5 \% / \mathrm{B} 2.5 \% / \mathrm{D} 1 \% / \mathrm{HT} / \mathrm{PS}$ & $22 \pm 0.1$ & 12.5 & 3.5 & Yes & Yes & $\mathrm{V}-2$ \\
\hline
\end{tabular}

Fire performance data for PS composites and their foams were listed in Tables 11 and 12. Compared with the data from Tables 11 and 12, samples no matter foamed or not, the LOI values decreased significantly and the vertical combustion performance decreased slightly with the increase of $\mathrm{Sb}_{2} \mathrm{O}_{3}$ content. Because $\mathrm{Sb}_{2} \mathrm{O}_{3}$ can promote the production of $\mathrm{SbBr}_{3}$ and $\mathrm{HBr}$ earlier by decomposing the bromine compound at lower temperature and $\mathrm{HBr}$ will most probably produce the retardant effect rather than $\mathrm{SbBr}_{3} \cdot{ }^{28,47}$ As mentioned above, the aromatic bromine has a higher decomposition temperature than the aliphatic bromine. Therefore, $\mathrm{Sb}_{2} \mathrm{O}_{3}$ plays a more important role when combined with the aromatic bromine to advance the release of FR substances, but it has negative effect when combined with aliphatic bromine which decomposition temperature is low because of producing more $\mathrm{SbBr}_{3}$ and less $\mathrm{HBr}$ resulting in hindering the dripping effect and flame retardant performance in gas phase at the initial stage of combustion. There was only $1 / 4$ aromatic bromine in the composites, so too much antimony would volatilizes aliphatic bromine as $\mathrm{SbBr}_{3}$ leading to reduce chain scission activity and then droplets which took away heat produced by molecular chain scission activity was weakened. As shown in Fig. 7, in

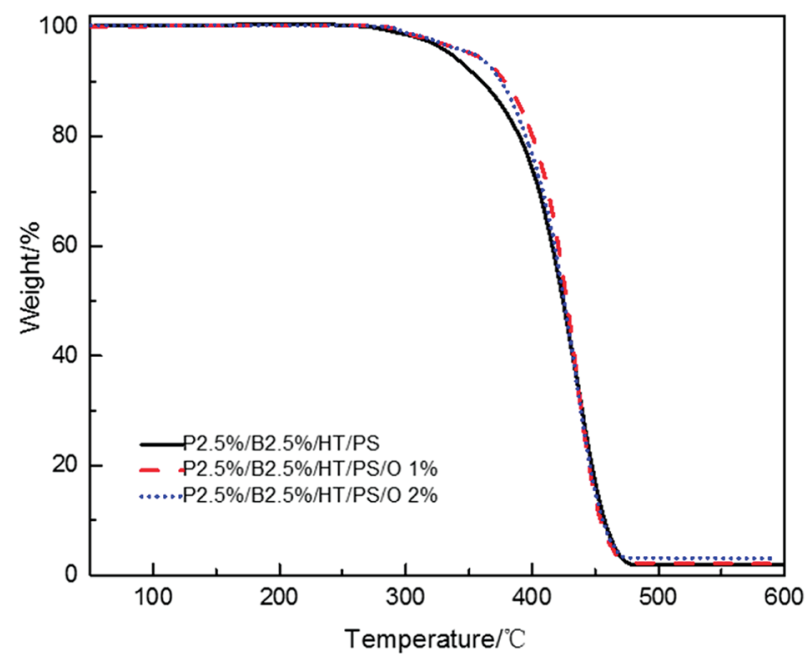

Fig. 9 TGA curves of PS composites with various OMMT content. nitrogen atmosphere, all the PS composites with $\mathrm{Sb}_{2} \mathrm{O}_{3}$ showed the higher decomposing temperatures compared with the PS composites without $\mathrm{Sb}_{2} \mathrm{O}_{3}$ and the thermal stability of PS composites was gradually improved with the increase of $\mathrm{Sb}_{2} \mathrm{O}_{3}$ content. As mentioned earlier, the increase of thermal stability would weaken the dripping effect.

In Fig. 8, pk-HRR values of P2.5\%/B2.5\%/S1.6\%/HT/PS were decreased into lower level than that of $\mathrm{P} 2.5 \% / \mathrm{B} 2.5 \% / \mathrm{HT} / \mathrm{PS}$. Moreover, HRR of $\mathrm{P} 2.5 \% / \mathrm{B} 2.5 \% / \mathrm{S} 1.6 \% / \mathrm{HT} / \mathrm{PS}$ was suppressed at the initial stage of combustion compared with $\mathrm{P} 2.5 \% / \mathrm{B} 2.5 \%$ / $\mathrm{HT} / \mathrm{PS}$. As mentioned above, in the container the heat was not able to be taken away in time by the droplets, the improvement of thermal stability of PS composites would weaken the combustion intensity of materials.

The av-EHC and THR values of P2.5\%/B2.5\%/S1.6\%/HT/PS had been reduced compared with $\mathrm{P} 2.5 \% / \mathrm{B} 2.5 \% / \mathrm{HT} / \mathrm{PS}$ or pure PS from Table 13, indicating that the combustion intensity was suppressed during the whole combustion process and the addition of $\mathrm{Sb}_{2} \mathrm{O}_{3}$ resulted in more incomplete combustion which was also evidenced by variation of av-COY and av- $\mathrm{CO}_{2} \mathrm{Y}$ values. This may reveal that $\mathrm{Sb}_{2} \mathrm{O}_{3}$ made the release of $\mathrm{FR}$ substance more durable instead of concentrated release. So the addition of $\mathrm{Sb}_{2} \mathrm{O}_{3}$ inhibited the dropping effect of PS

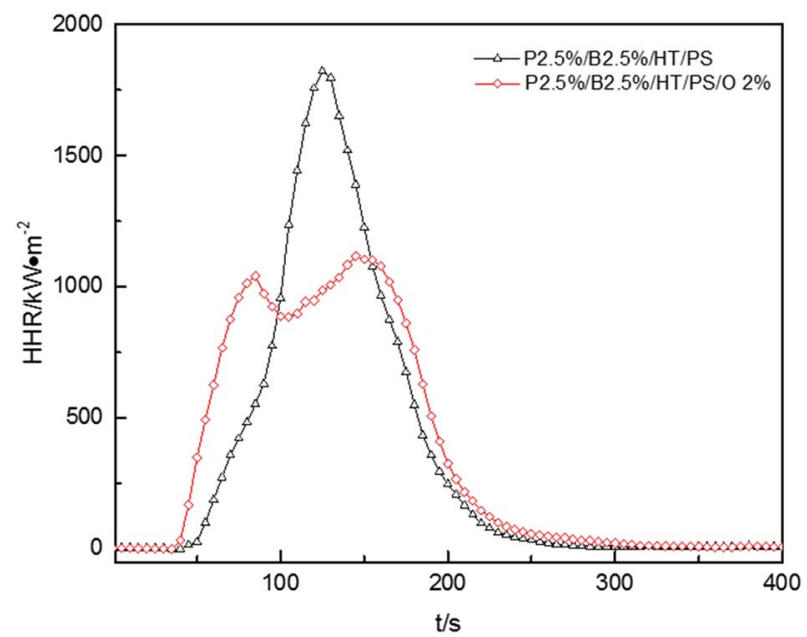

Fig. 10 Heat release rate (HRR) curves of PS composites. 
Table 15 The data of PS composites from cone calorimetry test

\begin{tabular}{llllll}
\hline Sample & pk-HRR $\left(\mathrm{kW} \mathrm{m}^{-2}\right)$ & THR $\left(\mathrm{MJ} \mathrm{m}^{-2}\right)$ & av-EHC $\left(\mathrm{MJ} \mathrm{kg}^{-1}\right)$ & ${\mathrm{av}-\mathrm{COY}\left(\mathrm{kg} \mathrm{kg}^{-1}\right)}^{\mathrm{av}-\mathrm{CO}_{2} \mathrm{Y}\left(\mathrm{kg} \mathrm{kg}^{-1}\right)}$ \\
\hline P2.5\%/B2.5\%//HT/PS & 1821 & 139.9 & 35.9 & 0.139 & 2.944 \\
P2.5\%/B2.5\%/D2\%/HT/PS & 1117 & 143.8 & 34.4 & 0.141 & 2.728
\end{tabular}

Table 16 LOI value and UL94 rating of PS and its composites

\begin{tabular}{|c|c|c|c|c|c|c|}
\hline Sample (resin) & LOI\% & av-t1 (s) & av-t2 (s) & Dripping & Ignition & UL94 rating \\
\hline P2.5\%/B2.5\%/HT/PS & $25.7 \pm 0.2$ & 0.4 & 0.4 & Yes & Yes & $V-2$ \\
\hline $\mathrm{P} 2.5 \% / \mathrm{B} 2.5 \% / \mathrm{G} 1 \% / \mathrm{HT} / \mathrm{PS}$ & $25.6 \pm 0.3$ & 0.5 & 0.3 & Yes & Yes & $\mathrm{V}-2$ \\
\hline
\end{tabular}

Table 17 LOI value and UL94 rating of PS and its composite foams

\begin{tabular}{|c|c|c|c|c|c|c|}
\hline Sample (foam) & LOI\% & av-t1 (s) & av-t2 (s) & Dripping & Ignition & UL94 rating \\
\hline $\mathrm{P} 2.5 \% / \mathrm{B} 2.5 \% / \mathrm{HT} / \mathrm{PS}$ & $30.7 \pm 0.4$ & 0.8 & 0.3 & Yes & Yes & $\mathrm{V}-2$ \\
\hline $\mathrm{P} 2.5 \% / \mathrm{B} 2.5 \% / \mathrm{G} 1 \% / \mathrm{HT} / \mathrm{PS}$ & $29.4 \pm 0.2$ & 0.4 & 0.3 & Yes & Yes & $\mathrm{V}-2$ \\
\hline
\end{tabular}

composites combustion, but $\mathrm{Sb}_{2} \mathrm{O}_{3}$ had a synergistic effect with PolyFR/BDDP/HT system to some extent which inhibited the combustion intensity of samples.

\subsection{Flame-retardant properties of PS with OMMT/PolyFR/ BDDP/HT}

In order to research the effect of OMMT on flame retardancy of PolyFR/BDDP/HT system, the OMMT was incorporated into PolyFR/BDDP/HT/PS composites.

The LOI value and the vertical combustion performance decreased significantly with the increase of OMMT content in Table 14. The LOI value of $\mathrm{P} 2.5 \% / \mathrm{B} 2.5 \% / \mathrm{O} 1 \% / \mathrm{HT} / \mathrm{PS}$ declined sharply to $22 \%$ and that of $\mathrm{P} 2.5 \% / \mathrm{B} 2.5 \% / \mathrm{O} 2 \% / \mathrm{HT} / \mathrm{PS}$ to $20.9 \%$ from $25.7 \%$. Simultaneously, the UL94 results of PS composites

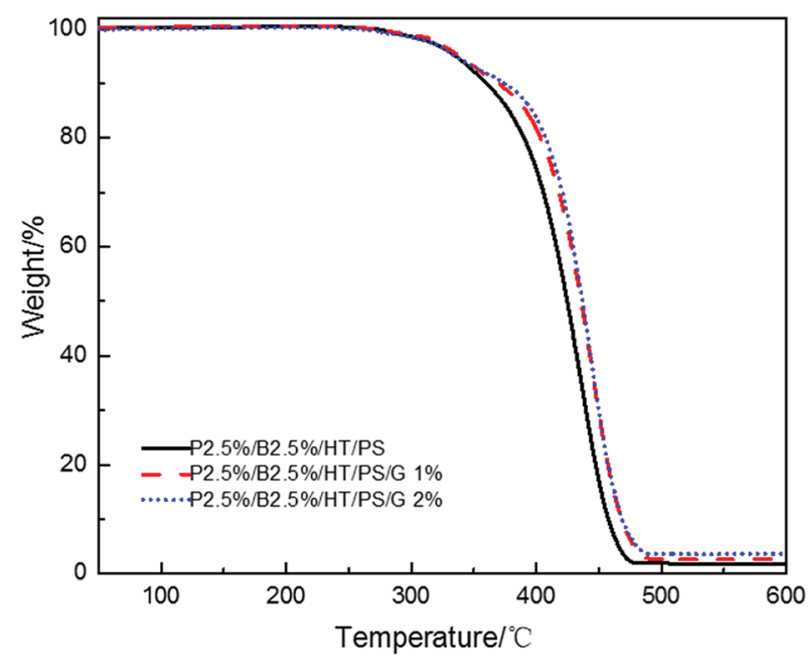

Fig. 11 TGA curves of PS composites with various graphite content. also exhibited the similar trend. In Table 14, P2.5\%/B2.5\%/ O1\%/HT/PS passed UL94 V-2 rating but its self-extinguishing time increasing to $12.5 \mathrm{~s}$ from $0.8 \mathrm{~s}$ and $\mathrm{P} 2.5 \% / \mathrm{B} 2.5 \% / \mathrm{O} 2 \% /$ HT/PS didn't even pass UL94 V-2 rating. The results showed the existence of antagonism FR effect between PolyFR/BDDP/ HT and OMMT. The addition of OMMT improved the thermal stability of PS composites during the process of composites combustion. It is more difficult to produce droplets to take away heat when composites is burned. The slower thermal decomposition of the PS composites with OMMT may be ascribed to the barrier and labyrinth effects of the dispersed silicate layers which hinder diffusion of volatile decomposition products within the PS composites. ${ }^{48,49}$ TGA tests were conducted and results were illustrated in Fig. 9. PS composites with OMMT showed higher decomposition temperature than PS composites.

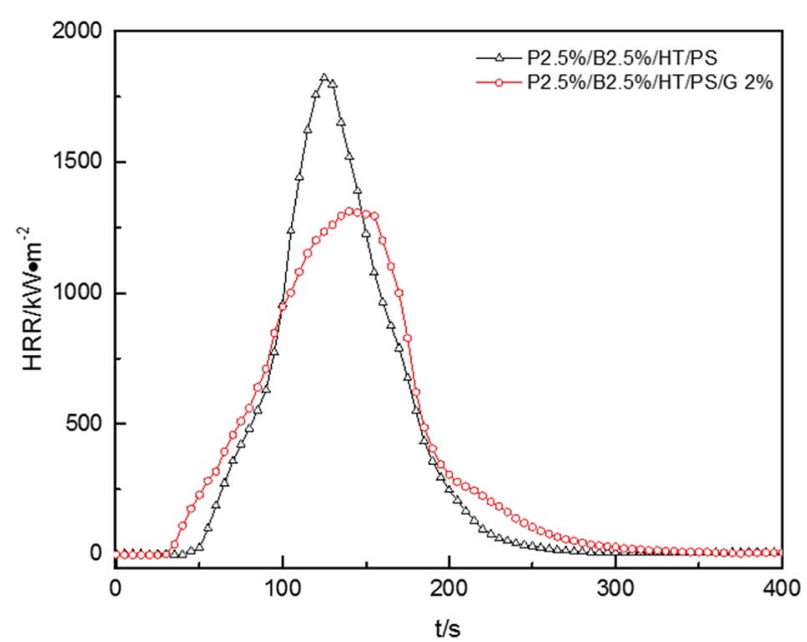

Fig. 12 Heat release rate (HRR) curves of PS composites. 
Table 18 The data of PS composites from cone calorimetry test

\begin{tabular}{|c|c|c|c|c|c|}
\hline Sample & pk-HRR $\left(\mathrm{kW} \mathrm{m}^{-2}\right)$ & $\mathrm{THR}\left(\mathrm{MJ} \mathrm{m} \mathrm{m}^{-2}\right)$ & av-EHC (MJ kg $\left.{ }^{-1}\right)$ & $\operatorname{av}-\operatorname{COY}\left(\mathrm{kg} \mathrm{kg}^{-1}\right)$ & av- $\mathrm{CO}_{2} \mathrm{Y}\left(\mathrm{kg} \mathrm{kg}^{-1}\right)$ \\
\hline $\mathrm{P} 2.5 \% / \mathrm{B} 2.5 \% / \mathrm{HT} / \mathrm{PS}$ & 1821 & 139.9 & 35.9 & 0.139 & 2.944 \\
\hline $\mathrm{P} 2.5 \% / \mathrm{B} 2.5 \% / \mathrm{G} 2 \% / \mathrm{HT} / \mathrm{PS}$ & 1312 & 144.3 & 35.1 & 0.127 & 2.825 \\
\hline
\end{tabular}
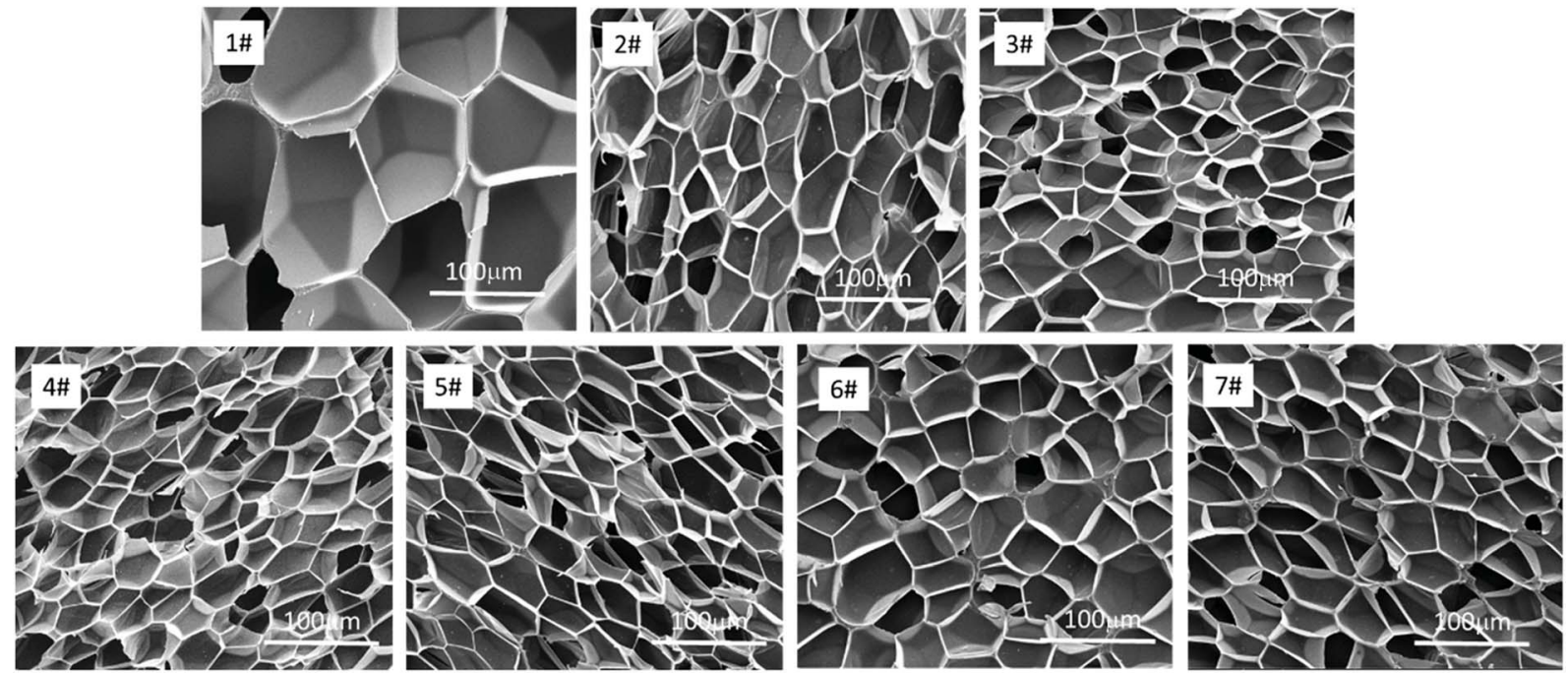

Fig. 13 SEM micrographs of FR PS composite foams. 1\#-PS, 2\#-P5\%/HT/PS, 3\#-P2.5\%/B2.5\%/HT/PS, 4\#-P2.5\%/B2.5\%/S0.8\%/HT/PS, 5\#P2.5\%/B2.5\%/S1.6\%/HT/PS, 6\#-P2.5\%/B2.5\%/G1\%/HT/PS, 7\#-P2.5\%/B2.5\%/G2\%/HT/PS.

The HRR curves for $\mathrm{P} 2.5 \% / \mathrm{B} 2.5 \% / \mathrm{O} 2 \% / \mathrm{HT} / \mathrm{PS}$ were shown in Fig. 10. The HRR of $\mathrm{P} 2.5 \% / \mathrm{B} 2.5 \% / \mathrm{O} 2 \% / \mathrm{HT} / \mathrm{PS}$ exceeded that of $\mathrm{P} 2.5 \% / \mathrm{B} 2.5 \% / \mathrm{HT} / \mathrm{PS}$ before $95 \mathrm{~s}$, and then reached a maximum of $1117 \mathrm{~kW} \mathrm{~m}^{-2}$ after a slight drop. The HRR of P2.5\%/B2.5\%/ $\mathrm{HT} / \mathrm{PS}$ fell rapidly after reaching a maximum of $1821 \mathrm{~kW} \mathrm{~m}^{-2}$. Reduction of the HRR peak and weakening of combustion intensity are the typical features of polymer layered silicate nanocomposites, as reported by J. W. Gilman, ${ }^{50}$ Huaili Qin ${ }^{51}$ and A. B. Morgan. ${ }^{52}$ Many studies ${ }^{51,53,54}$ have shown that the presence of clay nanocomposites promoted carbon formation and carbon with multilayer carbonaceous silicate structure was formed after pyrolysis of composites. This carbonaceous-silicate char will form a protective layer on the surface of the burning composites which isolates the underlying materials and slows the escape of volatile products during the combustion and degradation of composites and the little change of av-EHC, av-

Table 19 Cell morphology data of FR PS composite foams

\begin{tabular}{lllll}
\hline Sample & $\begin{array}{l}\text { Density } \\
\left(\mathrm{g} \mathrm{cm}^{-3}\right)\end{array}$ & $\begin{array}{l}\text { Expansion } \\
\text { ratio }\end{array}$ & $\begin{array}{l}\text { Cell size } \\
(\mu \mathrm{m})\end{array}$ & $\begin{array}{l}\text { Cell density } \\
(\text { cells per cm }\end{array}$ \\
\hline 1\# & 0.0989 & 10.1 & 110.5 & 0.49 \\
$2 \#$ & 0.0938 & 10.6 & 39.2 & 1.29 \\
$3 \#$ & 0.0838 & 11.9 & 38.4 & 1.83 \\
$4 \#$ & 0.0960 & 10.4 & 40.0 & 1.78 \\
$5 \#$ & 0.0865 & 11.5 & 41.5 & 1.83 \\
$6 \#$ & 0.1080 & 9.2 & 45.9 & 1.09 \\
$7 \#$ & 0.0970 & 10.3 & 41.6 & 1.56
\end{tabular}

COY and av- $\mathrm{CO}_{2} \mathrm{Y}$ also explained that the improvement in HRR was caused by burning process not in the gas phase. However, carbonaceous-silicate layer not only hindered the spread of volatile products by matrix resin but also by flame retardants. So on the other hand, the addition of OMMT in this system may have a bad effect on flame retardant. As the data listed in Table 15, THR of P2.5\%/B2.5\%/O2\%/HT/PS was a little bigger than that of $\mathrm{P} 2.5 \% / \mathrm{B} 2.5 \% / \mathrm{HT} / \mathrm{PS}$, which indicated that

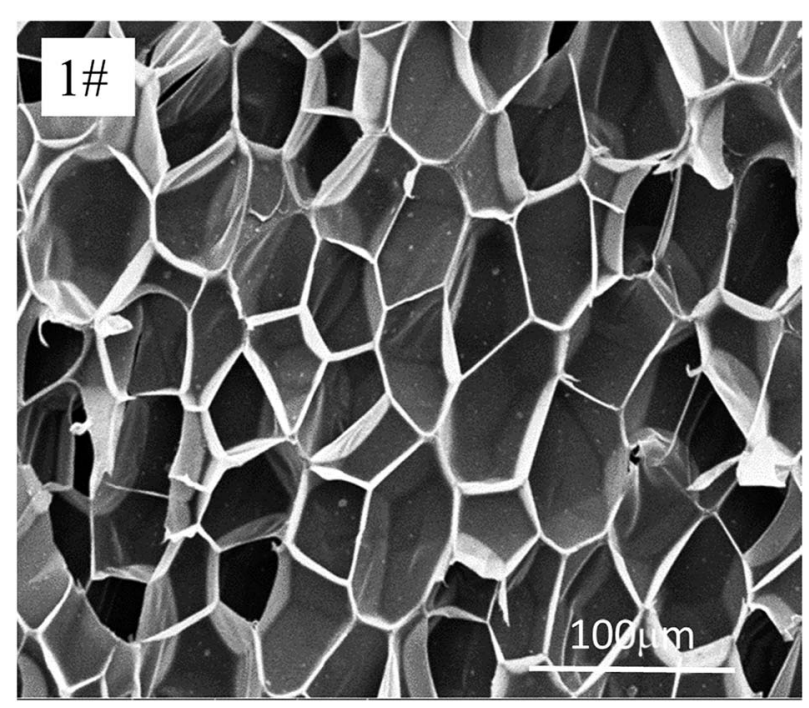

Fig. 14 SEM micrographs of FR PS composite foam. 

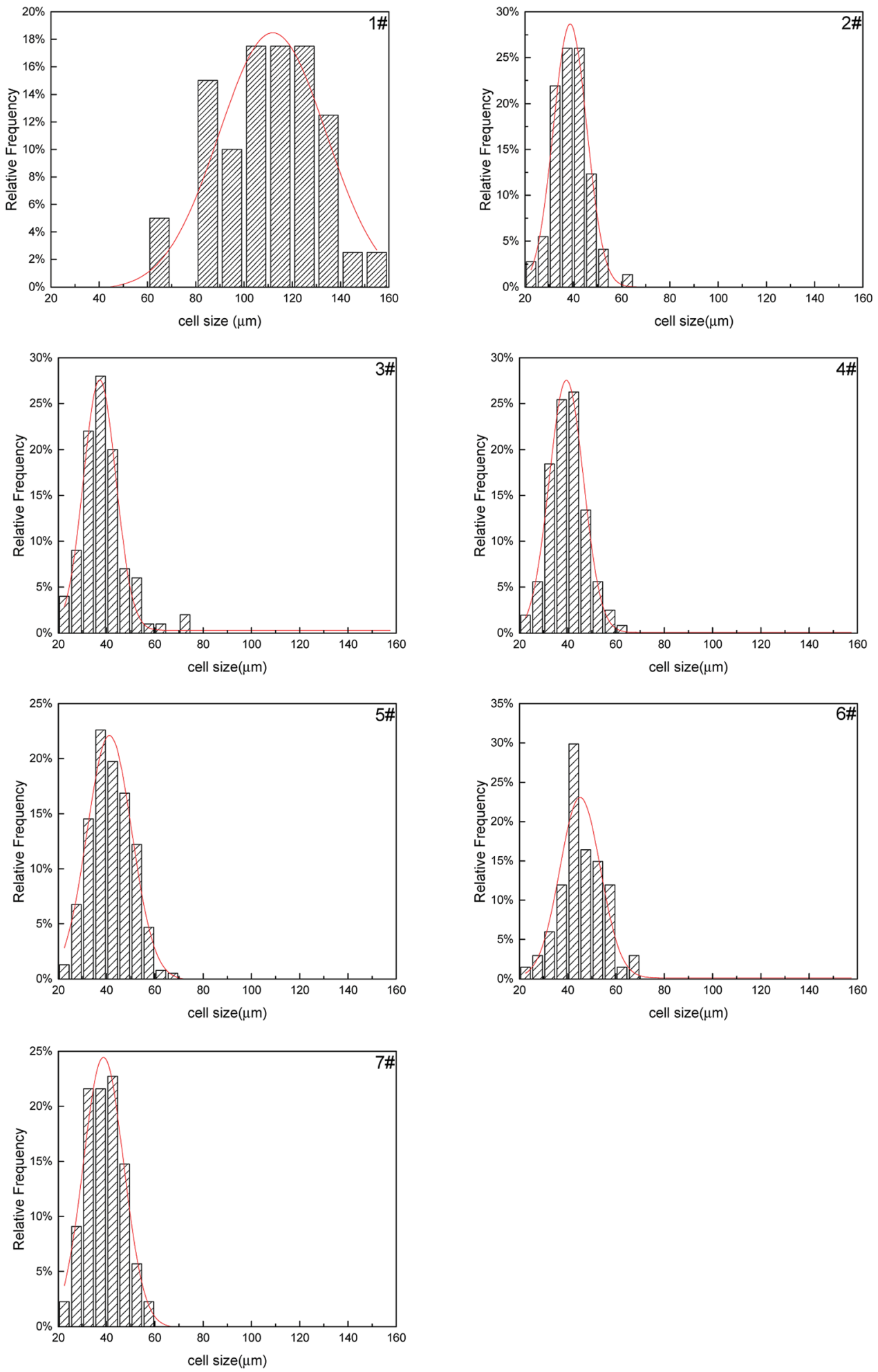

Fig. 15 Cell size distribution of FR PS composite foams. 1\#-PS, 2\#-P5\%/HT/PS, 3\#-P2.5\%/B2.5\%/HT/PS, 4\#-P2.5\%/B2.5\%/S0.8\%/HT/PS, 5\#P2.5\%/B2.5\%/S1.6\%/HT/PS, 6\#-P2.5\%/B2.5\%/G1\%/HT/PS, 7\#P2.5\%/B2.5\%/G2\%/HT/PS.

the burning process of $\mathrm{P} 2.5 \% / \mathrm{B} 2.5 \% / \mathrm{O} 2 \% / \mathrm{HT} / \mathrm{PS}$ intend to produce a longer duration fire. ${ }^{55}$ So the conclusion was that the addition of OMMT reduced burning intensity while hindering the effect of flame retardants severely in PolyFR/BDDP/HT system.
3.7 Flame-retardant properties of PS with graphite/PolyFR/ BDDP/HT

In order to research the effect of graphite of flame retardancy on PolyFR/BDDP/HT system, the graphite was incorporated into PolyFR/BDDP/HT/PS composites. 
As the data listed in Tables 16 and 17, no matter samples were foamed or not, the LOI value decreased in a small extent and the vertical combustion performance was no change with the increase of graphite content. Graphite is also layered structure just like layered silicates but would not form a similar intercalated-exfoliated structure. When addition of carbon particle, it would form a similar network structure which may impede the release of volatile products and produce barrier effect which can improve the thermal stability of PS composites. $^{56}$ The study investigated by Bettina Dittrich ${ }^{56}$ reported that carbon particle worked as anti-dripping agents. TGA tests were conducted and results were illustrated in Fig. 11, the thermal stability of PS composites were improved with the increase of graphite content which weakened the droplet effect leading to the reduction of LOI value.

Fig. 12, presented the HRR curves of P2.5\%/B2.5\%/HT/PS and $\mathrm{P} 2.5 \% / \mathrm{B} 2.5 \% / \mathrm{G} 2 \% / \mathrm{HT} / \mathrm{PS}$. The pk-HHR value of $\mathrm{P} 2.5 \% /$ $\mathrm{B} 2.5 \% / \mathrm{G} 2 \% / \mathrm{HT} / \mathrm{PS}$ was $1312 \mathrm{~kW} \mathrm{~m}^{-2}$ lower $509 \mathrm{~kW} \mathrm{~m}^{-2}$ than the value of $\mathrm{P} 2.5 \% / \mathrm{B} 2.5 \% / \mathrm{HT} / \mathrm{PS}$. A residue layer from the carbon particles would be formed during combustion. The dense and stable layer structure on the surface of the burning composites would act as a heat and mass transport barrier which delayed heat conduction to the underlayered material resulted in the better thermal stability of composites, therefore reducing combustion intensity. ${ }^{57}$ The other data listed in Table 18, such as av-EHC, av-COY and av- $\mathrm{CO}_{2} \mathrm{Y}$ values had no obvious change indicating the change of combustion performance was mainly caused by condensed phase. However, the change of THR was similar to that of the PS composite with OMMT also indicating a longer duration fire. So the addition of graphite inhibited the dropping effect of PS composites during combustion leading to the LOI value decreased in a small extent, but also inhibited the combustion intensity of samples.

\subsection{Foaming behavior of various PS composite samples}

The SEM images of the different PS composite foams and pure PS were shown in Fig. 13, and foaming parameters (cell size, density, expansion ratio, cell density) of all the composite foams were shown in Table 19. It was found that when PolyFR and HT was added into PS, the cell density of foams increased sharply from $0.49 \times 10^{8}$ to $1.29 \times 10^{8}$ cells per $\mathrm{cm}^{3}$, the cell size of PS composite foams (2\#) decreased from $110.5 \mu \mathrm{m}$ to $39.2 \mu \mathrm{m}$ obviously, the density and the expansion ratio just had a small change. The main reason was that PolyFR was not melted particles at $190{ }^{\circ} \mathrm{C}$ and $\mathrm{HT}$ was inorganic particle, PolyFR/HT played an efficient heterogeneous cell nucleation role in the foaming process, but the amount of HT was so small that it played a minor role in heterogeneous cell nucleation. A large number of white particles were observed in Fig. 14, indicating that microphase separation on the foam cell surface happened between filler and polystyrene. Compared with homogeneous nucleation, the activation energy of heterogeneous nucleation is lower, which makes it easier to nucleate on the interface of the two polymers. ${ }^{58}$ Compared with the sample $2 \#$, cell size, density, expansion ratio and cell density of samples (3\#-7\#) had no big change. As a kind of non-melting particle ${ }^{33}$ which was added into PS with a large contents, the interfaces of PS and PolyFR had provided a large number of heterogeneous cell nucleation points leading to cell nucleation of the system reaching saturation. Therefore, the addition of inorganic particles had no obvious effect on nucleation.

The cell size distribution of PS composite foams were shown in Fig. 15. Cell size distribution was a parameter to show the cell number within a certain range of cell size. The cell size distribution of PS foam (1\#) was mainly from $80 \mu \mathrm{m}$ to $140 \mu \mathrm{m}$. The cell size distribution of PS composite foams (2\#-7\#) were mainly from $30 \mu \mathrm{m}$ to $50 \mu \mathrm{m}$ but their cell size distribution had no obvious differences. As mentioned above, the addition of a large number of non-melting PolyFR particles led to cell nucleation of the system reaching saturation so that the addition of inorganic particles would not have a big change in cell size distribution.

\section{Conclusion}

PolyFR would be affected by shear stress and thermal oxidative degradation in practice leading to serious degradation. HT was able to added into the flame retardant system to improve the thermal stability of PolyFR because of the its ability to absorb $\mathrm{HBr}$ formed during thermal dehydrobromination of PolyFR to inhibit the autocatalytic degradation of the PolyFR. The LOI value of PS and PS foams containing 5\% PolyFR reached 26.8\% and $32.1 \%$, UL94 rating are V-2. With the increase of BDDP content and the decrease of PolyFR content the LOI values of PS composites and their foams decreased gradually. When incorporating $\mathrm{Sb}_{2} \mathrm{O}_{3}$ into the PS composites, it inhibited the dropping effect of PS composites combustion resulted in a decrease in LOI value, but $\mathrm{Sb}_{2} \mathrm{O}_{3}$ also had a synergistic effect with PolyFR/ BDDP to some extent, which inhibited the combustion of polymers by reducing and delaying HRR peak, THR, av-EHC. When OMMT existed in the flame retardant system, the flame retardancy of PS composites and their foams decreased sharply. These were attributed to the barrier and labyrinth effects of the dispersed silicate layers which hinder diffusion of volatile decomposition products within the PS composites leading to weakening of droplet effect and impede the circulation of $\mathrm{HBr}$. The addition of graphite into the flame retardant system had the same phenomenon as adding OMMT. The barrier and labyrinth effects of the dispersed graphite layers also leading to weakening of droplet effect and impede the circulation of $\mathrm{HBr}$, but flame retardancy wouldn't decrease that much like the composites with OMMT.

As a kind of non-melting particle, 2.5\% PolyFR provided a large number of heterogeneous cell nucleation points compared with pure PS which just had homogeneous nucleation which leading to cell nucleation of the system reached saturation. Therefore, the addition of $\mathrm{Sb}_{2} \mathrm{O}_{3}$, OMMT and graphite had no obvious effect on nucleation and cell size distribution.

\section{Conflicts of interest}

There are no conflicts to declare. 


\section{Acknowledgements}

This work was supported by the National Key Research and Development Program of China (2016YFB0302203 and 2016YFB0302205).

\section{References}

1 X. Han, J. Shen, H. Huang, D. L. Tomasko and L. J. Lee, Polym. Eng. Sci., 2007, 47, 103-111.

2 D. L. Tomasko, A. Burley, L. Feng, S.-K. Yeh, K. Miyazono, S. Nirmal-Kumar, I. Kusaka and K. Koelling, J. Supercrit. Fluids, 2009, 47, 493-499.

3 Y. Zhou, R. Bu, J. Gong, W. Yan and C. Fan, Exp. Therm. Fluid Sci., 2018, 92, 346-352.

4 C. Zhang, B. Zhu, D. Li and L. J. Lee, Polymer, 2012, 53, 24352442.

5 C. Zhang, B. Zhu and L. J. Lee, Polymer, 2011, 52, 1847-1855. 6 Z. Xing, M. Wang, G. Du, T. Xiao, W. Liu, D. Qiang and G. Wu, J. Supercrit. Fluids, 2013, 82, 50-55.

7 B. Cao, X. Gu, X. Song, X. Jin, X. Liu, X. Liu, J. Sun and S. Zhang, J. Appl. Polym. Sci., 2016, 134.

8 J. Q. Wang and W. K. Chow, J. Appl. Polym. Sci., 2005, 97, 366376.

9 S. Yi, J. G. Liu, J. Jin and J. Zhu, Chemosphere, 2016, 150, 431437.

10 M. Ezechias, S. Covino and T. Cajthaml, Ecotoxicol. Environ. Saf., 2014, 110, 153-167.

11 C. Koch, T. Schmidt-Kotters, R. Rupp and B. Sures, Environ. Pollut., 2015, 199, 26-34.

12 S. V. Levchik and E. D. Weil, Polym. Int., 2008, 57, 431-448.

13 G. Wang, X. Chen, P. Liu and S. Bai, J. Appl. Polym. Sci., 2016, 134.

14 Y. Shi, B. Yu, L. Duan, Z. Gui, B. Wang, Y. Hu and R. K. K. Yuen, J. Hazard. Mater., 2017, 332, 87-96.

15 Z.-M. Zhu, Y.-J. Xu, W. Liao, S. Xu and Y.-Z. Wang, Ind. Eng. Chem. Res., 2017, 56, 4649-4658.

16 G. Wang and S. Bai, J. Appl. Polym. Sci., 2017, 134, 45474.

17 H. Yan, J. Zhang, M. Zhang, X. Du, S. Ma and B. Xu, Adv. Polym. Technol., 2016, 35, 208-214.

18 B. Yuan, A. Fan, M. Yang, X. Chen, Y. Hu, C. Bao, S. Jiang, Y. Niu, Y. Zhang, S. He and H. Dai, Polym. Degrad. Stab., 2017, 143, 42-56.

19 Y. Han, Y. Wu, M. Shen, T. Li, Y. Wang, Q. Zhang and Z. Wang, Polym. Compos., 2017, 38, 1680-1688.

20 W. Xing, W. Yang, W. Yang, Q. Hu, J. Si, H. Lu, B. Yang, L. Song, Y. Hu and R. K. Yuen, ACS Appl. Mater. Interfaces, 2016, 8, 26266-26274.

21 J. Liu, M. Fu, M. Jing and Q. Li, Polym. Adv. Technol., 2013, 24, 273-281.

22 Z. Zhang, Y. Han, T. Li, T. Wang, X. Gao, Q. Liang and L. Chen, Synth. Met., 2016, 221, 28-38.

23 Y. Han, T. Li, B. Gao, L. Gao, X. Tian, Q. Zhang and Y. Wang, J. Appl. Polym. Sci., 2016, 133, 43047.
24 Z. Wang, S. Jiang and H. Sun, Iran. Polym. J., 2016, 26, 71-79. 25 Z. Guo, S. Ran and Z. Fang, J. Therm. Anal. Calorim., 2017, 128, 1719-1730.

26 S. Ran, C. Chen, Z. Guo and Z. Fang, J. Appl. Polym. Sci., 2014, 131, 4401-4404.

27 C. G. Zang, X. P. Cao and J. C. Zhang, Adv. Mater. Res., 2013, 652-654, 423-429.

28 J. Kaspersma, C. Doumen, S. Munro and A. M. Prins, Polym. Degrad. Stab., 2002, 77, 325-331.

29 H. Lu and C. A. Wilkie, Polym. Degrad. Stab., 2010, 95, 564571.

30 M. W. Beach, D. A. Beaudoin, I. Beulich, J. C. Bloom, J. W. Davis, H. M. Hollnagel, J. W. Hull, B. King, S. Kram, C. Lukas, M. Matteucci, T. Morgan and B. Stobby, Cell. Polym., 2013, 32, 229-236.

31 Additives for Polymers, 2015, 2015, 5-6.

32 Additives for Polymers, 2014, 2014, 8.

33 M. W. Beach, J. W. Hull, B. A. King, I. I. Beulich, B. G. Stobby, S. L. Kram and D. B. Gorman, Polym. Degrad. Stab., 2017, 135, 99-110.

34 M. Lewin and E. D. Weil, Fire Retard. Mater., 2001, 31-68.

35 J. Eichhorn, J. Appl. Polym. Sci., 2010, 8, 2497-2524.

36 M. W. Beach, N. G. Rondan, R. D. Froese, B. B. Gerhart, J. G. Green, B. G. Stobby, A. G. Shmakov, V. M. Shvartsberg and O. P. Korobeinichev, Polym. Degrad. Stab., 2008, 93, 1664-1673.

37 S. H. Park, S. T. Lim, T. K. Shin, H. J. Choi and M. S. Jhon, Polymer, 2001, 42, 5737-5742.

38 R. Bacaloglu and M. Fisch, Polym. Degrad. Stab., 1994, 45, 301-313.

39 P. Šimon, Polym. Degrad. Stab., 1992, 36, 85-89.

40 Y. Lin, J. Wang, D. G. Evans and D. Li, J. Phys. Chem. Solids, 2006, 67, 998-1001.

41 J. Yu, L. Sun, C. Ma, Y. Qiao and H. Yao, Waste Manag., 2016, 48, 300-314.

42 Y.-J. Lin, D.-Q. Li, D. G. Evans and X. Duan, Polym. Degrad. Stab., 2005, 88, 286-293.

43 X. Zhang, L. Zhou, H. Pi, S. Guo and J. Fu, Polym. Degrad. Stab., 2014, 102, 204-211.

44 V. Babushok, W. Tsang, G. T. Linteris and D. Reinelt, Combust. Flame, 1998, 115, 551-560.

45 W. Xi, L. Qian, Y. Qiu and Y. Chen, Polym. Adv. Technol., 2016, 27, 781-788.

46 Y. Cao, L. Qian, Y. Chen and Z. Wang, J. Appl. Polym. Sci., 2017, 45126.

47 T. Handa, T. Nagashima and N. Ebihara, Fire Mater., 2010, 3, 61-67.

48 Y. Hu, S. Wang, Z. Ling, Y. Zhuang, Z. Chen and W. Fan, Macromol. Mater. Eng., 2003, 288, 272-276.

49 M. Masoomi, R. Bagheri, L. Ahmadkhanbeigi and M. Asgari, J. Appl. Polym. Sci., 2014, 131, 178-184.

50 J. W. Gilman, Appl. Clay Sci., 1999, 15, 31-49.

51 H. Qin, Q. Su, S. Zhang, B. Zhao and M. Yang, Polymer, 2003, 44, 7533-7538. 
52 A. B. Morgan, Polym. Adv. Technol., 2006, 17, 206-217.

53 M. Zanetti, T. Kashiwagi, a. L. Falqui and G. Camino, Chem. Mater., 2002, 14, 881-887.

54 M. Zanetti, G. Camino, D. Canavese, A. B. Morgan, F. J. Lamelas and C. A. Wilkie, Chem. Mater., 2002, 14, 189-193.
55 R. Shen, L. C. Hatanaka, L. Ahmed, R. J. Agnew, M. S. Mannan and Q. Wang, J. Therm. Anal. Calorim., 2016, 128, 1443-1451.

56 B. Dittrich, K.-A. Wartig, D. Hofmann, R. Mülhaupt and B. Schartel, Polym. Degrad. Stab., 2013, 98, 1495-1505.

57 B. Schartel and A. Weiß, Fire Mater., 2010, 34, 217-234.

58 J. S. Colton and N. P. Suh, Polym. Eng. Sci., 1987, 27, 493-499. 